\title{
OS PROCESSOS LITERÁRIOS E A CONSTRUÇÃO DA IMAGEM DO INTELECTUAL ENGAJADO**
}

\section{Gisèle Sapiro}

Tradução de Jorge Thierry Calasans e Clara de F. Ferreira

Em seu livro As regras da arte, Pierre Bourdieu analisa o processo de autonomização do campo literário em relação ao mercado e às pressões econômicas. Ele também evoca, ocasionalmente, a conquista da autonomia em relação à ideologia e à moral dominante, mas sem desenvolver esse aspecto. É esta dimensão do processo de autonomização do campo literário que eu quis estudar em meu livro sobre La responsabilité de l'écrivain [A responsabilidade do escritor], cujo fio condutor é o conceito de responsabilidade. A autonomia do campo literário não se constrói unicamente pela oposição à lógica do mercado, mas também por meio de lutas contra definições heterônomas do papel social do escritor e de sua responsabilidade. O conceito de responsabilidade permite compreender a relação entre as definições sociais e penais dos direitos e deveres dos

* Conferência proferida no $36^{\circ}$ Encontro Anual da Anpocs, no dia 23 de outubro de 2012, em Águas de Lindóia - SP. escritores e seu próprio entendimento do ofício.

A definição da responsabilidade do escritor é de fato uma questão de lutas que vão muito além do mundo das letras:

- Ela está codificada no direito por meio das restrições à liberdade de expressão - é a responsabilidade penal - que a transformam, portanto, em uma questão de Estado (na França, é o Estado que processa aqueles que violam essas restrições, diferentemente dos Estados Unidos, onde os processos são efetuados na maioria dos casos por meio de denúncias).

- Ela é também um assunto da Igreja, que tem a intenção de exercer um controle sobre as consciências.

- Com a alfabetização e o aumento do número de leitores, torna-se também um assunto de médicos, sociólogos, criminologistas e de empresários da moral (ligas de moralidade). 
- Por fim, ela é um assunto dos próprios escritores, que devem ajustar as exigências inerentes à sua profissão às expectativas sociais das quais são alvo.

A restrição da liberdade de expressão determinou, desde sempre, as práticas de escrita, induzindo não somente hábitos de autocensura como também estratégias de evasão da responsabilidade autoral, como ocorrem nos gêneros literários, tais como a fábula, a alegoria, a narrativa histórica, a ficção. No entanto, como observado por Lewis Coser (1970, p. 7), a censura está, mais do que qualquer outro fator, na origem da aliança de muitos intelectuais com as forças do liberalismo e do radicalismo. Além disso, os escritores elaboraram, em grande parte, sua ética de responsabilidade se confrontando com essas expectativas sociais e se autonomizando. De fato, a partir do século XVIII, é elaborada uma ética da responsabilidade do escritor que se diferencia da responsabilidade penal e que se baseia na construção histórica da imagem do intelectual, da qual escritores, de Voltaire a Sartre, passando por Zola, representam a encarnação suprema. Esta ética reivindica valores próprios do mundo intelectual, o "verdadeiro", o "belo". Eles fundamentam as lutas pela liberdade de expressão travadas, desde o século XVIII, em nome da "verdade", do direito ao conhecimento e do direito a exercer um papel crítico na sociedade para "esclarecer a opinião" e permitir aos cidadãos desenvolverem o seu próprio julgamento. Mas será que essa liberdade significa que se pode dizer tudo? As palavras não têm nenhum efeito? $\mathrm{E}$, caso tenham, que responsabilidade isso cria para o escritor?

São nestas lutas que se afirmaram duas posturas opostas, mas que têm como ponto em comum a reinvindicação de sua autonomia com relação às definições heterônomas da responsabilidade:

- A arte pela arte: recusa de subordinar a arte à moral (de Flaubert a Robbe-Grillet).

- A imagem do intelectual engajado em causas universais como a justiça ou a liberdade (de Zola a Sartre).

Os processos literários constituem um espaço de observação privilegiado desses debates, do confronto entre essas diferentes concepções de responsabilidade, que são explicitadas e tornadas públicas. Revelam as lutas em torno da definição da responsabilidade penal do autor e os argumentos apresentados pela defesa, que definem os contornos da ética profissional do escritor.

O surgimento dessa ética da responsabilidade do escritor é parte de uma história mais ampla da responsabilidade que abordarei na primeira parte deste artigo, apoiando-me em Foucault e no sociólogo durkheimiano Paul Fauconnet. Em seguida, tratarei das questôes em torno das quais é definida a responsabilidade do autor e sua evolução, que é correlativa às transformaçôes da moralidade pública. $\mathrm{Na}$ terceira parte, mostrarei de que forma a teoria sartreana de literatura engajada constitui um momento-chave da redefinição da responsabilidade do escritor que leva ao extremo a sua dimensão subjetiva ao mesmo tempo em que reafirma sua autonomia.

\section{O processo de subjetivação da responsabilidade}

Como já demonstrado por Michel Foucault, a responsabilidade penal tem desempenhado um papel importante na afirmação da "função autor", pela atribuição de uma série de discursos publicados a um autor. É fato que, historicamente, a responsabilidade penal precede a propriedade literária. Antes de ser um bem, um produto cujo autor pode reivindicar a propriedade, o discurso foi um ato, susceptível de ser punido. A responsabilidade penal foi introduzida na legislação real em 1551, com o Édito de Châteaubriant, que tornava obrigatória a colocação do nome do impressor e do autor em toda e qualquer publicação. Em 1554, a faculdade de Teologia de Paris adotou o nome do autor como um princípio de classificação de livros censurados.

Essa paternidade, num primeiro momento imposta pelas autoridades com o intuito de controlar a circulação dos discursos, seria assumida pelos escritores no século seguinte, como base para suas aspiraçōes em fazer valer o direito sobre sua obra, aspirações estas que só se tornaram realidade na França na 
segunda metade do século XVIII, com a sentença de 1777 que reconhecia os direitos autorais.

Foi também nessa época que o conceito de responsabilidade surgiu em seu significado jurídico moderno. Ora, os escritores não tardaram a se voltar contra o Estado e seus poderes, elaborando, a partir do século XVIII, a sua própria ética de responsabilidade, distinta e muitas vezes oposta à sua responsabilidade penal: é o que fazem os filósofos do século XVIII ao proclamar a autonomia da razão, que se recusa a subordinar-se a outros princípios que não aos dela mesma, se emancipando, dessa forma, das rédeas da religião.

Esta afirmação de uma ética da responsabilidade do escritor é parte do processo de subjetivação da responsabilidade. Assim como sugerido por Paul Fauconnet, as definições de responsabilidade variam entre a objetividade e a subjetividade. A responsabilidade objetiva pura pode ser ilustrada pelo ritual de expiação, ao passo que a responsabilidade subjetiva pura, representada pela moral religiosa, condena os pensamentos e as intenções carregadas de culpa. A responsabilidade jurídica é um compromisso entre essas duas tendências opostas. As infraçōes são constatadas a partir de um fato externo, que constitui o seu elemento material e que é o produto de uma ação atribuível a um autor, do qual se examina, na sequência, o caráter voluntário, ou seja, a intenção - trata-se do elemento moral ou subjetivo da infração. $\mathrm{O}$ estabelecimento do elemento material é incumbido a um grupo de especialistas: juízes, advogados, polícia.

O surgimento da responsabilidade subjetiva é o resultado de um processo histórico de imaterialização e individualização da responsabilidade. A imaterialização está intimamente relacionada com a evolução da concepção religiosa do pecado. $\mathrm{Na}$ Idade Média, as pessoas eram julgadas por atos, e a relação entre o agente e o ato podia ser puramente externa. A partir do século XII, a moral religiosa católica desenvolve uma concepção subjetiva da responsabilidade que desloca o foco do pecado para o pecador, da culpa para a intenção. Esse processo é reforçado pela ascensão do individualismo, que contribui com a institucionalização da confissão (Hahn, 1986). ${ }^{1}$ Estreitamente ligada aos processos de controle social, a subjetivação da responsabilida- de pode ser observada também na esfera judicial, regida a partir dessa época pelo direito romano-canônico, no qual a confissão é necessária.

Esta nova concepção do ato e da culpabilidade rompe com as interpretações mágicas da relação entre o agente e o evento: os eventos só podem ser qualificados de atos se uma relação interna causal, isto é, uma intenção, os une a seu autor. Tal causalidade supõe a noção de livre arbítrio, sobre a qual se baseia o conceito subjetivo da responsabilidade, isentando, dessa forma, os seres que não a possuem, isto é, os animais, as crianças, os doentes mentais, aqueles considerados, por lei, incapazes. A subjetivação da responsabilidade no tocante à moral religiosa ocorre conjuntamente à interiorização da pena, tornando-se uma contrição. Uma divisão do trabalho ocorre entre os órgãos judiciais que julgam os atos e os punem com uma intenção corretiva (Foucault, 1993) e a instância religiosa, responsável pela consciência. ${ }^{2}$

A imaterialização da responsabilidade faz com que o sentimento individual se transforme em responsabilidade social (Idem, p. 366). Inicialmente questionado pela Reforma Protestante, que chega ao limite da lógica da individualização e da imaterialização da responsabilidade com a interiorização do exame de consciência (introspecção), ${ }^{3}$ o controle dessa responsabilidade subjetiva por teólogos e clérigos é novamente contestado no século XVIII por filósofos e escritores que iniciam uma laicização da moral, fundamentando-a na razão: Kant forneceu a fórmula mais elaborada, com o seu princípio da autonomia da vontade, que fez da liberdade a condição da responsabilidade (cf. Schneewind, 2001).

Esses novos moralistas, que são os escritores, recusam submeter-se às instâncias que exercem o poder espiritual e pretendem substituí-las, reivindicando o direito de criticá-las em nome da razão. Para tornar públicos os seus vereditos, eles dispõem de um instrumento temível: o impresso, que lhes dá acesso às consciências de um número crescente de indivíduos. A missão que se impõem é justamente a de dar clareza à "opinião pública”. Mas qual o fundamento de sua legitimidade? "Como escritores que não possuíam nem status, nem honras, nem riquezas, nem responsabilidade, nem poder, se tornaram, de fato, os principais lí- 
deres políticos da época, e até mesmo os únicos, pois, enquanto outros governavam, somente eles detinham a autoridade?", questiona Tocqueville (1967, p. 231).

Diferentemente dos artistas, os escritores nunca constituíram uma corporação, nem uma ordem, nem uma profissão reconhecida como tal. O exercício da atividade literária não requer nenhum "direito de ingresso" formal, pois essa atividade não supõe aprendizado técnico comparável ao dos artistas ou dos músicos. Caso necessite de alguma instrução, não se trata de uma competência certificada, sancionada por títulos acadêmicos, como é o caso das profissóes jurídicas ou de ensino. A representação do escritor como um ser livre e indeterminado se enraíza, assim, em um fato social.

Em contrapartida, ela fundamenta a postura profética reivindicada pelos letrados a partir do século XVIII. Diante das categorias organizadas no seio do Estado absolutista e do clero, essa prática individual, livre e muitas vezes desinteressada da crítica moral, social e política, cujo poder não deriva nem da tradição, nem da legalidade, mas unicamente do carisma exercido pelo autor sobre um público de leitores ao qual ele atende às expectativas, permite compreender que a posição dos escritores na estrutura social é similar à do profeta, tal qual a análise de Max Weber (1974, t. 1 , cap. $3, \$ 4$, pp. 320 e ss.). Ao contrário do padre ou do teólogo, mandatado por uma instituição, o escritor, como o profeta, não tem mandato de ninguém. Se ele fala em nome da razão, é somente o seu talento, fonte de seu "carisma", que fundamenta seu crédito e seus direitos à sua conquista. No entanto, o processo de laicização e o combate do Iluminismo contra os preconceitos e o dogmatismo favorecem, desde os meados do século XVIII, a transferência da função sagrada do mundo religioso para o mundo das letras. Contra a religião estabelecida, os letrados difundem uma nova fé filosófica, humanista e que obedece apenas aos mandamentos da razão. Em uma época em que se desenvolve o culto dos grandes homens, o escritor, quando não se faz passar por legislador, como no caso de Rousseau (Bénichou, 1996, pp. 45-48; Bonnet, 1998), quer parecer um santo laico.
Contudo, esta posição lhe confere direitos e também uma nova responsabilidade. Ao associar o discurso a um indivíduo, seu autor, e não mais a uma instituição ou a uma categoria, os representantes deste novo tribunal agravam sua própria responsabilidade em sua dimensão individual e subjetiva. Eles se expõem a uma dupla sentença, ou seja, por um lado, eles mesmos se submetem ao veredito do tribunal que eles alegam esclarecer: o público; por outro, eles assumem o risco de serem julgados justamente em nome dos preconceitos que eles se permitem combater, e que formam a base da moral oficial tal qual codificada na lei. A primeira fundamenta a responsabilidade moral do escritor moderno, a segunda, sua responsabilidade penal.

Sem ser procurador de ninguém, o profeta, e somente ele, deve se submeter à sanção da sociedade. Se a correção da profecia é suficiente para legitimá-la e assegurar a seu autor a "imortalidade", ou seja, a glória póstuma, que é o maior reconhecimento que um escritor pode almejar, a falsa profecia é, no entanto, punida com a morte. De acordo com Paul Fauconnet, "o alto valor moral da repressão dá valor à responsabilidade, que é sua condição" (1920, p. 300). A declaração real de 1757, que pune com a morte o culpado de ter elaborado ou ordenado a elaboração, impresso, vendido ou distribuído escritos que atacam a religião, abalam a mente, ofendem a autoridade real e perturbam a ordem e a tranquilidade do Estado, constitui uma boa indicação do valor simbólico conferido à responsabilidade autoral, mesmo se, de acordo com Malesherbes, a própria gravidade desta declaração assegurava a sua inaplicabilidade (cf. Chartier, 1994, p. 18).

O evento principal em relação ao qual essa responsabilidade vai se definir é a Revolução Francesa. Não somente pelo fato de ela ter dado início ao regime de liberdade de imprensa na França, mas também por aparecer, no imaginário coletivo daquela época e, sobretudo, no período posterior, como se tivesse surgido, única e exclusivamente, do poder das palavras. "Considera-se, com razão, a filosofia do século XVIII como uma das principais causas da Revolução", escreveu Tocqueville (1967, p. 63). Compartilhada pelos revolucionários, que fizeram de Voltaire e Rousseau os seus precursores, 
e por seus adversários os mais ferrenhos, a crença na responsabilidade dos escritores nos eventos revolucionários é, sem dúvida, um dos núcleos principais do imaginário nacional francês. ${ }^{4} \mathrm{E}$ é constitutiva da definição penal da responsabilidade do escritor, pairando sobre todos os debates referentes à liberdade de imprensa no século XIX.

\section{Dos crimes cometidos por meio da imprensa}

Como se define essa responsabilidade penal? A transposição da responsabilidade penal, tal qual definida por Fauconnet, aos crimes escritos de dupla dimensão, objetiva e subjetiva, desvenda os desafios da definição da responsabilidade penal do escritor:

- Por um lado, deve haver um ato material. Não se castiga indivíduos por seus pensamentos condenáveis ou exclusivamente por suas intençôes. Esse ato material é a publicação. É a razão pela qual, na legislação, o primeiro responsável é aquele que imprime; antes da divisão do trabalho entre editor e impressor, era o autor; mas quando, no início do XIX, surge a figura do editor, ele passa a ser o primeiro responsável, sendo o autor apenas seu cúmplice (o que facilita os processos judiciais no caso de reedições de obras de autores falecidos, como as do Marquês de Sade).

- Por outro lado, a dimensão subjetiva pode agravar ou atenuar a responsabilidade objetiva: deve-se demonstrar que os responsáveis e seus cúmplices agiram com a intenção de prejudicar (o que permitirá isentar o impressor pela lei de 1881, salvo se for provado que agiu com conhecimento de causa); outra consequência é que o autor é sempre punido de forma mais severa do que o editor, apesar de este último ser o principal responsável. Isto é válido para o livro, mas não para a imprensa: na imprensa, concebida como uma empresa, o gerente é o responsável, antes dos próprios autores dos artigos (estes, no século XIX, muitas vezes anônimos; a responsabilização implicará, posteriormente, na exigência de inclusão dos nomes dos autores).

\section{Em que bases se estabelece essa responsabilidade?}

A responsabilidade penal do autor refere-se, em primeiro lugar, ao conteúdo de seus escritos: eles ofenderam a moral pública ou os costumes, transgrediram os valores fundamentais da sociedade, atacaram o governo? Mas não se trata apenas do conteúdo. A responsabilidade do autor também é definida em relação à forma e à materialidade do suporte, concebidos como indicadores da responsabilidade objetiva tanto quanto da responsabilidade subjetiva. Ela também se baseia na teoria dos efeitos sociais do escrito, que formam os contornos da responsabilidade do autor, isto é, a responsabilidade subjetiva. Vou rever resumidamente essas diferentes dimensōes que definem a responsabilidade penal do autor.

\section{O conteúdo}

Com relação ao conteúdo, ao final da Segunda Guerra Mundial, o estudo dos processos literários do início do século XIX permitiu constatar uma evolução da definição da moral pública. Se a liberdade de imprensa foi decretada, sob a Revolução Francesa, pela Declaração Universal dos Direitos do Homem, a sua aplicação foi de curtíssima duração. Apenas no início do século XIX, sob a monarquia parlamentar da Restauração, é que foram promulgadas, em aplicação à Constituição de 1814, as primeiras leis que definem e fixam os limites da liberdade de imprensa. A lei protege, em primeiro lugar, de qualquer ataque ou crítica, o regime monárquico. Protege também a religião. De fato, se o princípio de liberdade de consciência e de discussão filosófica estabelecido pela Constituição de 1814 para evitar as guerras de religião é respeitado, a lei criminaliza qualquer questionamento do princípio da "imortalidade da alma": as doutrinas materialistas foram consideradas um crime até o advento da grande lei republicana de 1881 . Por fim, a lei condena as ofensas aos costumes, um crime ainda de pouca autonomia em relação aos desafios políticos e religiosos. Ao longo de todo o século XIX, e mesmo até a Terceira República, a ofensa aos costumes servirá de pretexto para processar os textos de oposição que não se enquadram como crime político. 
A ofensa à moral se torna autônoma sob o regime de ordem moral do Segundo Império, instaurado em 1852, após a revolução de 1848 e do golpe de estado de Louis-Napoléon Luís Bonaparte. Esse regime promove uma moral burguesa cujos pilares são a família e a propriedade. $\mathrm{O}$ processo contra Flaubert em 1857 por conta de Madame Bovary é, a este respeito, exemplar, pois viola estes dois pilares da ordem social: Emma Bovary comete um adultério que resulta na destruição de sua família além de dilapidar a fortuna da mesma, o que causa sua ruína. No entanto, de acordo com o advogado de Flaubert, o fato de seu cliente provocar a morte de sua heroína em meio a sofrimentos atrozes prova que o romance não é uma apologia ao adultério. Tal argumento é, no entanto, insuficiente aos olhos do procurador imperial. A morte de Emma não basta para absolver as ofensas à moral e ao bom gosto cometidos por Flaubert em seu romance, e ele cita cenas que considera "lascivas", principalmente a famosa cena na qual Emma parte numa carruagem com seu amante, onde nada é descrito e tudo é apenas sugerido (só se leem as ordens dadas ao cocheiro, que podem ser compreendidas como expressões relacionadas com o ato sexual: "mais rápido" etc.). Além disso, Emma comete suicídio, o que corresponde a uma ofensa adicional à moral. Flaubert é, no entanto, absolvido, ao contrário de Baudelaire, que é julgado poucos meses mais tarde por sua coletânea de poemas Les fleurs du mal, e é condenado. A absolvição de Flaubert se dá pelo fato de seu advogado ter sido capaz de demonstrar que Madame Bovary era um romance moral: ele demonstra os efeitos nocivos dos livros ruins sobre uma mulher de origem modesta (Emma havia lido a literatura romântica em sua infância), à qual inculcaram ideias e ambiçôes para elevar-se acima de sua condição. Note-se que a mobilidade social é uma das principais preocupaçôes dos conservadores nessa época. O fato é que Flaubert é absolvido em nome daquilo por que fora condenado: os supostos efeitos nocivos dos livros ruins. Voltarei a este ponto.

Sob a Terceira República, a imprensa é liberalizada por meio da grande lei republicana de 1881. A religião é privatizada, ou seja, não está mais protegida por lei. A secularização da moralidade pública é, no entanto, acompanhada por sua nacionalização. Apesar de respeitar o princípio da liberdade de opinião, o regime republicano não se protege, na lei, como tal. É, no entanto, em nome do interesse nacional que os opositores ao regime serão processados, em particular os anarquistas, acusados de envolvimento em atos terroristas, o que impede de enquadrá-los no princípio da liberdade de opinião. Em contrapartida, a ofensa à moral é endurecida: a República deve provar sua respeitabilidade num momento de intensificação e de internacionalização da luta contra a pornografia, sobretudo pelo fato de a França ser considerada um dos centros de produção e de divulgação da literatura pornográfica. Esta luta é engajada em nome do interesse nacional. Ela ocorre num contexto de medicalização da sexualidade, que se tornou uma questão de higiene nacional, e se articula com a luta contra o malthusianismo, o alcoolismo, a sífilis, a prostituição de rua, os "desvios" sexuais, o suicídio, que se constituem tanto como sintomas quanto como causas de uma patologia do "corpo social". A estrutura nor$\mathrm{mal} /$ patológica, que tem por referência o paradigma médico, vem substituir as noçōes religiosas de "bem" e de "mal".

Os escritores naturalistas tornam-se o alvo da onda de repressão que se inicia em 1884. Eles são perseguidos por ofensa aos bons costumes, o que põe a nação em perigo. Se não se ousa atacar o mestre, Zola, que faz muito sucesso, são seus discípulos que pagam a conta. Charles Bonnetain, processado por seu romance Charlot samuse [Charlot se diverte], que trata de um onanista vítima de uma tara hereditária, filho de pai alcoólatra e mãe que se prostitui após a morte do marido. Em sua defesa, Bonnetain, como a maioria dos demais escritores naturalistas, argumentou o caráter científico de sua iniciativa, pois, como se sabe, Zola queria tornar a literatura uma ciência experimental. Ele será absolvido, tendo o júri reconhecido que o tom do romance era triste e, consequentemente, não constituía uma defesa do onanismo.

Outro escritor naturalista, Louis Desprez, acusado de ofensa aos bons costumes pelo livro Autour d'un clocher [Ao redor de um campanário], que narra os amores de um padre e de uma professora num estilo rabelaisiano, decidiu assumir pessoalmente a 
sua defesa, fundamentando-se na crítica ao conceito de ofensa aos bons costumes (republicada sob o título "Pour la liberté d'écrire" [Pela liberdade de escrever]). Segundo ele, a ofensa aos bons costumes pela literatura é indefinivel por não haver corpo de delito; procesam-se os autores por sua suposta intenção. Ele denuncia a hipocrisia que consiste na proibição de descrever um ato sexual quando descrições detalhadas de assassinatos se estendem por todas as páginas dos jornais. Foi condenado a um mês de prisão. A detenção teria agravado sua doença e ele morre poucos meses mais tarde, aos 28 anos de idade.

O processo de Lucien Descaves ilustra ainda mais a nacionalização da moralidade nesta época. Descaves é acusado de injúria contra o exército e de ofensa aos bons costumes por ter descrito os hábitos militares numa época em que o exército se torna uma instituição sagrada da nação (a ofensa aos bons costumes permitia fortalecer o caso, pois as penas por injúria ao exército eram mais brandas). Apesar de se tratar de um romance, o promotor, para agravar o caso, qualifica o livro de "escrito infame" e considera seu autor um "malfeitor da escrita". Em sua defesa, o advogado invoca a necessidade de dizer a verdade com o intuito de melhorar o estado das coisas; é este, segundo ele, o papel de escritores e dos jornalistas em um regime democrático. A única questão que, a seus olhos, se coloca é a de saber se o que é descrito por seu cliente é verdadeiro. No entanto, Descraves se apoiou não somente em sua própria experiência (o serviço militar tinha se tornado obrigatório para todos), mas também nos julgamentos dos conselhos de guerra. Descraves foi absolvido.

Por fim, os processos de depuração que se seguiram à Segunda Guerra Mundial fazem parte de outro quadro legislativo que também ilustra a nacionalização da moral: o das leis condenando atos de traição, especialmente o crime de "inteligência com o inimigo", passível de pena de morte ou de prisão perpétua, no qual foram inscritos os escritores ultracolaboradores, bem como o de indignidade nacional para crimes menos graves, punidos com a degradação nacional que acarreta a privação dos direitos cívicos. Esses processos trazem à tona um debate entre a acusação e a defesa: a acusação qualifica os textos incriminados de atos de traição por corresponderem à propaganda em favor do inimigo e a ataques contra os franceses (as denúncias coletivas e individuais dos gaullistas, dos comunistas e dos judeus); a defesa denuncia os delitos de opinião: os colaboradores serão processados por suas opiniōes políticas, o que contraria o princípio de um regime de liberdade de imprensa (sabendo que esses mesmos escritores tinham comemorado a supressão da liberdade de imprensa pelo ocupante alemão e pelo regime autoritário de Vichy). Os colaboradores reivindicam a autonomia de pensamento com relação ao ocupante: é com justa causa que Robert Brasillach, que será condenado à morte e executado, pôde arguir que seu antissemitismo e seu antiparlamentarismo se ancoraram em uma tradição bem francesa.

Esses processos são, no entanto, o testemunho da conquista da relativa autonomia da literatura: em primeiro lugar, os escritores não são condenados por seus escritos propriamente literários, mas por seus textos jornalísticos ou aqueles que possuem uma característica evidente de propaganda; em segundo lugar, os escritores mais reconhecidos por seus pares são relativamente poupados; em terceiro, censuram-se os escritores por não terem exercido a sua função crítica em relação à política de colaboração com o regime.

Este é, portanto, o conteúdo das acusações interpostas contra os escritores, cuja evolução é o testemunho das transformações da moral pública. Como vimos, os processos constituem um espaço de lutas em torno da interpretação dos textos. Mas, como vimos, o conteúdo não é suficiente para determinar a responsabilidade do autor; há também outras dimensões, sobretudo a forma e o gênero, que representam um desafio para a interpretação dos textos.

A forma

Do ponto de vista da forma do texto, o gênero supõe hábitos de leitura ou uma forma de recepção. Considera-se, por exemplo, no início do século XIX, que a canção é um gênero leve, ao contrário da poesia: é quando imprime suas canções que o cancioneiro liberal Béranger é processado; enquanto o 
seu defensor invoca a leveza do gênero, o promotor as qualifica de "odes" e de "panfletos em rima". De fato, o libelo, o panfleto é, ao contrário da canção, um gênero evidentemente suspeito de conter uma conotação política e uma visão sediciosa: isto se deve à sua forma curta que permite alcançar um público mais amplo e menos culto. Assim também durante o processo de Lucien Descaves por ofensa aos bons costumes, na Terceira República, o promotor tentará, para agravar o caso, convencer que o romance é na verdade um panfleto: ele o qualifica de "panfleto infame".

Além do gênero, os procedimentos formais também podem ser fonte de debates contraditórios sobre a interpretação de uma obra. Creio que as escolhas formais de Flaubert pesaram mais nas acusaçôes contra ele do que o tema do adultério, que era comum na literatura e no teatro daquela época. Flaubert opta, primeiramente, por um narrador impessoal, que não julga seus personagens, mas os observa do alto, com uma objetividade tingida de ironia. Ora, tanto a crítica quanto o promotor o acusam desta falta de julgamento. $\mathrm{O}$ uso de uma nova técnica na França, o discurso indireto livre, que consiste em entrar no pensamento do autor sem indicar a mudança de ponto de vista por aspas ou pela forma indireta, conduz o promotor imperial a confundir o ponto de vista do autor com aquele de seu personagem. É o caso, por exemplo, da cena em que Emma volta do primeiro encontro com seu amante: ela se olha no espelho e Flaubert escreve "nunca tinha estado tão bonita", o que, aos olhos do promotor, é uma prova que Flaubert glorifica o adultério; o advogado do escritor lhe responde que este é o ponto de vista de Emma, é ela quem se vê bela no espelho.

O estilo e o vocabulário também são objeto de ataque, quando considerados ofensivos aos costumes e ao bom gosto. Aliás, Flaubert se autocensurou muito, como testemunham seus manuscritos: ele excluiu, por exemplo, as palavras "puta" e "bordel". Contudo isso não impediu que ele fosse atacado por seu estilo realista e pela crueza de suas descrições, o que é paradoxal, uma vez que escreveu seu romance “em ódio ao realismo", que ele parodia (as descriçōes mais realistas são reservadas à imaginação de Emma, a seus devaneios, e não à realidade que a rodeia).
Sob a Terceira República, numa época em que a língua se torna uma questão nacional, os escritores naturalistas também serão acusados pela crueza de suas descrições. A crítica se refere a uma "literatura pútrida", e eles são acusados de "obscenidade" perante a lei. A língua, assim como os procedimentos formais, é aspecto central na acusação feita pelos naturalistas. Creio que ela seja uma das razões para esse fracasso da literatura em se construir como conhecimento especializado, num momento em que o paradigma científico se ergue como um referencial de políticas públicas e ocorre uma divisão do trabalho em especialidades: médicos, criminologistas, psiquiatras, psicólogos etc. Esta divisão do trabalho em especialidades priva os escritores de muitas áreas que eram de sua competência. Eles devem reafirmar seu poder simbólico. É o que tentou Zola ao querer fazer da literatura uma ciência experimental. Mas, ao contrário dos especialistas que usam as luvas do vocabulário técnico, e que gozam, assim, de uma imunidade perante a lei (é o caso dos médicos), os escritores naturalistas escrevem numa linguagem comum; e vão além, eles introduzem no discurso impresso a linguagem do meio que observam. Dessa forma, acabam contaminados pelo objeto observado.

Ao mesmo tempo em que definem a responsabilidade objetiva (ofensa aos bons costumes), o gênero, a língua e o estilo podem ser considerados, nos processos, indícios da intenção do autor. Enquanto a acusação tenta fazê-los parecer indícios de sua intenção de prejudicar, como vimos nas tentativas de requalificar as obras como panfletos, a defesa, ao contrário, os considera uma prova do projeto estético ou intelectual do escritor: por exemplo, a ambição realista de descrever a realidade da maneira mais exata e verídica possível. Essa intenção do autor, bem como a de seu editor, se determina também com relação ao suporte, que é considerado um indício do público alvo.

\section{O suporte e o público alvo}

Com efeito, a materialidade da publicação, o seu suporte (livro ou jornal), bem como a espessura do volume, também são levados em conta na determinação da responsabilidade: se o texto 
pode atingir um público amplo, trata-se de uma circunstância agravante. Consequentemente, os textos publicados na imprensa são mais penalizados do que livros.

Da mesma forma, como já comentado, o panfleto é considerado perigoso por ser um texto curto, suscetível de atingir um público amplo. Acusa-se, assim, o autor de ter querido incitar à rebelião. Uma obra de grande espessura e o público restrito à qual ela se destina constituem, de maneira oposta, circunstância atenuante invocada pela defesa nos casos de Flaubert, Baudelaire e dos naturalistas.

A problemática do suporte torna-se uma questão central com a alfabetização e a expansão da educação que se segue ao desenvolvimento fulgurante da edição e da imprensa. A democratização do acesso à leitura provoca terríveis pesadelos entre os guardiōes da ordem social. Desde o início do século XIX, os ultrarreacionários e a Igreja iniciam um combate contra as edições populares de baixo custo, que visam um público mais popular que as tradicionais fraçôes de letrados. Entre os novos leitores e os leitores considerados vulneráveis, existem as classes populares, a juventude e, sobretudo, as mulheres, consideradas mais frágeis e influenciáveis do que os homens (elas são infantilizadas em todas as esferas da sociedade, não possuindo direitos cívicos, autonomia em relação a seus maridos etc.).

Essa hierarquização dos públicos de acordo com a classe, o gênero e a raça é baseada em uma crença sobre os efeitos sociais da leitura, que é um outro componente da definição da responsabilidade do escritor.

\section{Os supostos efeitos da obra}

A crença nos supostos efeitos da obra subentende teorias semieruditas sobre a recepção que são elaboradas desde o século XVII, e evoca, em particular, Platão: baseia-se numa crença compartilhada sobre os efeitos nocivos dos livros ruins e, portanto, no poder performático das palavras. Essa crença imaterial foi desenvolvida pela Igreja na época de grande desenvolvimento da impressão, no século XVII. No século XVIII, os médicos, competindo com o clero quanto ao domínio reservado da esfera imaterial, desenvolvem o conceito de "contágio moral". A
Revolução Francesa alimentará esta crença: a ideia de que foram os livros que fizeram a revolução é compartilhada pelos revolucionários e contrarrevolucionários.

Em contrapartida, os escritores desenvolveram dois tipos de argumento: o primeiro, que caracteriza a arte pela arte, tende a negar os efeitos sociais da arte e a afirmar a dimensão puramente estética da obra; o segundo, característica da tradição realista, afirma que a literatura não faz nada mais do que descrever a realidade. Ora, não somente o autor não é responsável, mas ele faz a obra salutar tornando a verdade pública, contra a hipocrisia burguesa. Foi desse modo que Flaubert, para quem ambos os argumentos são válidos, reivindica apenas responsabilidade sobre a forma de seus escritos.

A ideia dos efeitos da obra permite um deslocamento da responsabilidade subjetiva para a responsabilidade objetiva, pois tais efeitos podem ser independentes das intençôes do autor, como ocorre no julgamento do processo de Flaubert. Esse argumento se desenvolve paralelamente à ampliação do número de leitores devido à alfabetização: críticos conservadores e empresários da moral estabelecem uma distinção entre o público culto, capaz de uma leitura distanciada, "desinteressada" de acordo com o termo utilizado por Kant para caracterizar o prazer estético, e o público de novos leitores, cuja leitura é definida pela identificação, a atração pelo útil e o agradável, em oposição ao prazer do esteta. Emma Bovary encarna perfeitamente essa figura de leitora pequeno-burguesa que possui uma relação utilitária com os livros: ela usa suas leituras tanto com finalidades práticas (para decorar sua casa), quanto para se dar emoçôes (ela grita de terror, à noite, lendo romances), confundindo permanentemente a arte e a vida, como no palco da ópera onde ela acredita, por um momento, que o tenor canta para ela e que irá levá-la com ele.

A expansão do público de leitores cria, portanto, para o escritor, novas responsabilidades, independentemente de suas intençôes. Contra essa concepção, que fundamentara por muito tempo as teorias cultas da literatura, Oscar Wilde, promotor $\mathrm{da}$ arte pela arte, reposicionou a responsabilidade para o leitor em seu livro Retrato de Dorian Gray: com efeito, os pecados de Dorian nunca são des- 
critos, o que força os leitores a projetarem a sua imaginação.

No entanto, o reposicionamento da responsabilidade objetiva é reforçado pelo paradigma da degeneração e das teorias hereditárias de Lombroso, com repercussões em vários empresários $\mathrm{da}$ moral. Bem antes do nazismo, vê-se surgir sob a pena do sociólogo Jean-Marie Guyau e, em seguida, do ensaísta Max Nordau, a representação de artistas como seres degenerados, desprovidos de senso moral e antissociais, constituindo, consequentemente, um perigo para a ordem social. Em seu livro publicado em 1894, Nordau toma como exemplo os decadentes e Oscar Wilde, que tinha acabado de ser condenado por homossexualismo. A condenação do escritor contribuiu para levar a descrédito a opção da arte pela arte, enquanto os processos dos naturalistas lançam dúvidas sobre a empreitada realista.

A questão do senso moral dos escritores e artistas remete à questão ética da responsabilidade do escritor, último componente da responsabilidade que obriga, agora, a pessoa do autor.

\section{A ética da responsabilidade do escritor}

De acordo com o Fauconnet, o sujeito escolhido para receber a pena é o substituto do crime; ele o simboliza. Como demonstrado pelo fato de ele ser sempre mais punido do que os outros, quando não se trata de publicações póstumas, é o autor que melhor simboliza os crimes escritos em relação às representações morais ou jurídicas. Substituto do crime, o paciente é, ele próprio, objeto de representaçôes coletivas, que variam de acordo com a sociedade e com a época.

Ora, se o autor é o melhor símbolo dos crimes escritos, é porque aqui a identificação do paciente e do delito atinge seu ápice. Em primeiro lugar, a expressão "autor" favorece em si a identificação entre o autor do escrito e o autor do crime, mesmo quando se trata, em realidade, somente de cumplicidade nos termos da lei.

Por outro lado, o autor é quem melhor simboliza o crime, pois a relação que ele mantém com seus escritos, de acordo com as representaçôes em vigor naquela época, é tripla: relação de metonímia, de semelhança e de causalidade. Se retomarmos a análise de Foucault, o autor se define pela compreensão do conjunto dos escritos que lhe são imputáveis. Entre o autor e cada um de seus escritos existe uma relação que vai do todo à cada parte: $M a d a-$ me Bovary é um dos livros que guardamos sob o nome de Flaubert; a expressão "o autor de Madame Bovary" é uma sinédoque para designar ao mesmo tempo o autor de L'éducation sentimentale etc. Originalmente codificada pela acusação penal, essa representação fundou a reivindicação da propriedade moral da obra pelo seu autor.

Essa definição do autor pelo conjunto de suas obras subentende ao mesmo tempo argumentos de acusação e de defesa no processo. Uma das estratégias da acusação para agravar a responsabilidade do autor poderia ser a de tentar atribuir-lhe a autoria de outros escritos, não reivindicados. Inversamente, a defesa poderia negar a autoria do escrito, como no caso de Céline, que contestava ser o autor das cartas publicadas na imprensa colaboracionista em seu nome. ${ }^{5}$ Mas esses casos de negação eram raros e geralmente só funcionavam se os escritos fossem anônimos ou publicados sob um pseudônimo.

$\mathrm{Na}$ maioria das situações, a relação de metonímia entre autor e seus escritos era, ao contrário, pressuposta pela defesa, quando ela contestava a interpretação da obra feita pela acusação, invocando o princípio da integridade da obra - os trechos só fazem sentido num todo, é o que Flaubert e seu advogado defendiam - e o projeto global do autor atestado por suas obras anteriores: por exemplo, a disposição dos naturalistas em descrever os males da sociedade.

A relação metonímica é reforçada pela representação metafórica da escrita como uma emanação da pessoa do autor, testemunhada pela célebre frase de Diderot, reivindicando o reconhecimento da obra como um bem:

Qual é o bem que pode pertencer a um homem se uma obra fruto de seu espírito, fruto único de sua educação, de seus estudos, de seu tempo, de suas noites em branco, de suas pesquisas, de suas observaçôes, se as horas as mais belas, os melhores momentos de sua vida, se os seus próprios pensamentos, os sentimentos de 
seu coração, a parte de si mesmo a mais valiosa, aquela que nunca morre, aquela que o imortaliza, não lhe pertence? (Diderot, 1976).

$\mathrm{Na}$ verdade, a propriedade literária repousa sobre a originalidade da forma e não sobre o seu conteúdo. ${ }^{6}$ É o que a liga à pessoa. Essa abordagem personalizada do direito autoral contribuiu para a codificação do direito moral que é inalienável no direito francês. Apenas o direito de exploração pode ser concedido. De acordo com essa concepção, a obra não pode ser considerada um simples bem comercial (o que, no entanto, é permitido pelo copyright anglo-saxão).

A obra, emanação da pessoa do autor, com ele se parece: "diz-se que um autor se retrata naquilo que escreve", lembra o advogado de Béranger, dr. Dupin, durante o processo de 1822 (Procès fait aux chansons de P.-J. Béranger, 1828, p. 57). Se a pessoa do autor pode ser identificada em cada um dos seus escritos, a moral da obra remete à moral do autor. A personalização da responsabilidade é, neste caso, extrema, devido às estreitas relaçôes internas e psicológicas que se supõe entre o autor e seus escritos.

O caso de Baudelaire é paradigmático desta identificação da moral do autor e da moral da obra: apesar da precaução tomada pelo promotor Pinard em distingui-las, não se deixou de atribuir ao poeta os vícios descritos em Les fleurs du mal. Essa identificação decorre tanto das convenções de leitura associadas à poesia lírica, que remetem à subjetividade do autor e aos temas tratados, quanto da sua condenação no processo de 1857 , que a corrobora e constitui, para o poeta, uma verdadeira mácula. Baudelaire tentará sempre se distanciar desta acusação.

"Mas é raro que o indivíduo seja tão semelhante ao seu crime, que nada os diferencie. $\mathrm{Na}$ maioria das vezes um exame minucioso mantém a dualidade. Sob um determinado aspecto, o indivíduo é um bom símbolo do crime; mas sob outro, é algo totalmente diferente" escreve Fauconnet (1920, p. 352). Para os escritores, a estratégia de defesa consiste em tentar distinguir o autor de sua obra, fornecendo garantias quanto à sua moralidade, sinceridade e boa-fé. A propriedade, a fortuna, o pertencimento às classes dominantes parecem constituir, em si, garantias de moralidade, enquanto a honestidade, a situação matrimonial, a devoção familiar, a boa reputação são as únicas provas que podem ser fornecidas por aqueles que não as possuem. No entanto, devido à forte identificação do autor com seus escritos, estes argumentos clássicos eram insuficientes.

Recorrer à ficção é uma forma de o autor se diferenciar de seus personagens, muitas vezes utilizados para burlar a censura. Mas este método não era suficiente, tendo em vista a convenção segundo a qual o narrador, identificado ao autor, devia definir um juízo de valor sobre seus personagens, como visto no caso de Flaubert. No entanto, a longo prazo, a distinção entre autor, narrador e seus personagens tornou-se uma convenção da literatura moderna; os meios de distanciamento vão da ironia e/ou da postura objetiva do intelectual que estuda um meio social (retomada, após Flaubert, pelos naturalistas) às técnicas narrativas adotando uma perspectiva interna ao universo fictício, por meio do testemunho ou do monólogo interior.

Por fim, a relação entre o autor e seus escritos parece ilustrar de forma paradigmática a interpretação imaterial da relação de causalidade entre o sujeito e o crime, que cria a responsabilidade subjetiva. Neste caso, o elemento material e o elemento moral parecem se confundir; o caráter voluntário é, a priori, uma certeza: os escritos aparecem como provas materiais da intenção objetivada. Essa representação, apesar de parecer uma evidência, nada tem de necessário ou mesmo de universal: basta mencionar a figura do poeta $\mathrm{da}$ antiguidade que se exprime sob o efeito da inspiração das musas e não reivindica, portanto, a autoria de seu discurso. Se ela aparece como consequência lógica da apropriação da obra por seu autor, sugere, inversamente, que o reconhecimento do direito do autor em se apropriar de sua obra se deve à imputação que fundamenta a sua responsabilidade penal, em conformidade com a análise de Foucault e, de forma mais geral, ao processo de subjetivação da responsabilidade. A definição subjetiva da responsabilidade repousa na noção de livre arbítrio. Como dissemos, seu surgimento está intimamente ligado ao processo de individualização. No entanto, como visto, o escritor aparece em representa- 
ções coletivas, como a encarnação suprema do individualismo e da liberdade.

A partir do momento em que se pressupóe o livre arbítrio e a relação de causalidade, trata-se de procurar os motivos que levaram o escritor a cometer o crime escrito pelo qual ele é processado.

Do ponto de vista jurídico, as motivações compõem os álibis do crime. Quanto aos escritores, em relação aos quais se pressupõe, em geral, que tenham agido racionalmente, podemos reagrupá-los em quatro categorias principais: a crença pessoal, o amor pela glória, a venalidade e o desejo de prejudicar. Existe, entre essas quatro categorias, uma gradação de acordo com o objetivo do ato de publicação. Essas motivações gerais assumem um significado específico na esfera intelectual em comparação aos valores que são próprios deste espaço.

A crença pessoal pode estabelecer uma circunstância atenuante, na medida em que se refere tanto à liberdade de expressão quanto à liberdade de discussão filosófica, ou ainda às regras específicas da literatura (autonomia), e também quando ela é considerada racional em relação a valores, de acordo com a classificação proposta por Max Weber: livre para elaborar o seu próprio sistema de pensamento e de torná-lo público, o autor que age por convicção pessoal, o escritor que se submeteu às restriçōes de sua arte, é considerado como se tivesse agido de boa fé, sem necessariamente a intenção de prejudicar ou sem ter previsto as consequências desses atos. A sinceridade e a boa-fé são, então, circunstâncias atenuantes. Considera-se, pois, que o acusado tenha cometido um erro, que ele tenha sido enganado. Retomando a expressão formulada por Max Weber dessa autonomia (1959, pp. 192-193), a acusação geralmente opõe à "ética da convicção" uma "ética da responsabilidade”. Essa é a razão pela qual a defesa tenta frequentemente responsabilizar os outros, passando assim a ocupar uma posição hierárquica superior ou de autoridade: um chefe, um superior, um intelectual. Durante o processo dos naturalistas, alguns advogados responsabilizaram o seu mestre, Zola, o que remete ao princípio da dominação carismática. Durante o processo de purificação, o argumento da defesa remetia frequentemente à autoridade legal do Marechal Pétain, o que funda- menta a ação racional sobre a legalidade. Assim, o célebre panfletista Henri Béraud, que publicava um jornal com tiragem de 600 mil exemplares antes da guerra e era conhecido por seus ataques contra personalidades políticas, afirma nos interrogatórios feitos pela polícia: "como um simples cidadão como eu poderia por em dúvida a autoridade do Marechal?".

A acusação poderia então repreender o acusado por seu servilismo, sua falta de independência, que tem por característica a fraqueza de caráter, traço tipicamente "feminino". É dessa forma que se desenha, durante a Liberação de Paris da ocupação nazista, a figura do "traidor".

Por outro lado, a acusação também se esforça para demonstrar que o ato de publicação não foi apenas determinado por valores, mas também - e sobretudo - por interesses menos puros. $\mathrm{O}$ amor pela glória e a venalidade são circunstâncias agravantes, pois, neste caso, o autor agiu por interesse pessoal desconsiderando as consequências de seus atos. A metáfora comumente utilizada para designar esse tipo de ação é a "prostituição", de acordo com a analogia subjacente entre vender seu corpo ou vender seus escritos, o que remete à personalização da noção de autor e à identificação deste último com sua obra. A busca pela glória pode levar autores ambiciosos a transgredir a lei exclusivamente para que falem deles e para acessar, por este meio, a celebridade. É a acusação feita pelo comissário do governo ao escritor colaboracionista Robert Brasillach em seu julgamento. O desejo de se tornar famoso, de adquirir uma reputação, mesmo que sulfurosa, é, no imaginário social, um dos "pecados" mais comuns do escritor ambicioso. Este expediente pode parecer desprezível para escritores que condenam o sucesso fácil e desconfiam de reputaçôes baseadas no escândalo. Todas estas ações são definidas como racionais em relação a um objetivo que é ou a intenção de prejudicar ou um interesse pessoal que orientou, conscientemente, uma ação condenável.

Além do debate sobre a interpretação dos textos, as estratégias da defesa para atenuar a responsabilidade penal consistem em negar a intenção de prejudicar. Esta negação pode ocorrer de diversas maneiras, que podem ser classificadas de acordo 
com as formas da racionalidade explicitadas por Max Weber (1974, t. I, pp. 55-56).

A negação suprema significa invocar a irracionalidade da ação. Como vimos, a definição moderna de responsabilidade aplica-se apenas aos seres capazes, ou seja, nas nossas sociedades, o adulto normal. As crianças, os alienados, os mortos, os animais são considerados incapazes. No entanto, a partir do século XIX, o escritor oscila entre duas figuras: a do pensador ou do intelectual, encarnação suprema da responsabilidade subjetiva, e a do artista, por vezes comparado a uma criança ou a um alienado, sendo a sua genialidade considerada um tipo de anormalidade. Essa construção social da figura do artista aparece, do ponto de vista que aqui nos interessa, como uma maneira de isentá-lo de sua responsabilidade. Realmente, nessa época, a doença mental tornou-se um argumento atenuante da responsabilidade penal dos acusados. Em alguns processos de escritores durante a Liberação, a defesa alegou a fragilidade nervosa do autor, sua hipersensibilidade e falta de equilíbrio psíquico. No requisitório sobre o caso Céline durante a Liberação, o procurador geral adjunto, que tentava atenuar sua responsabilidade, considerou que tal homem era incapaz de colaborar com quem quer que fosse e lamenta de não ter podido mandá-lo examinar por um psiquiatra (notemos que Céline alegava uma lesão que teria sofrido na cabeça durante a Primeira Guerra Mundial) (Gibault, 1985, p. 234). Ezra Pound, condenado em 1945 por seus engajamentos fascistas, foi julgado doente e internado.

No entanto, em muitos processos literários, não é a irracionalidade mas a racionalidade com relação a valores que era alegada em um sistema de defesa que consistia geralmente na reivindicação de uma autonomia de valores literários: o autor tinha agido racionalmente em relação a valores específicos à sua atividade. Essa ética profissional do ofício do escritor foi construída pela incorporação, por parte dos eruditos e outras profissōes intelectuais e artísticas, de valores específicos, tais como a beleza, a verdade, a objetividade, a sinceridade (Cassagne, 1997 , p. 86). Isso me conduz para a última parte, que será, não se preocupem, bem mais breve.

\section{Da responsabilidade do escritor ao engajamento do intelectual}

Esses valores foram reinvestidos e universalizados nas lutas políticas com as quais se engajaram no final do século XIX, como uma forma de reafirmar seu poder simbólico no momento da profissionalização da esfera política que os privava de uma das áreas que até então era de sua competência. Desde o século XVIII, dizer a verdade publicamente assumindo riscos correspondia a uma marca de coragem do escritor que assume seu dever perante o público (Sapiro, 2006b). A perseguição pelo poder assegura-lhe um crédito diante do público: Victor Hugo escreve a Baudelaire dizendo que sua condenação é a melhor condecoração que o regime imperial podia lhe conceder. Inicialmente usada por Voltaire no caso Calas, a estratégia de alteração da relação de força com a justiça foi posta em prática por Zola no caso Dreyfus, com o seu "J'accuse" [Eu acuso], dirigido contra a justiça e o governo que condenaram um inocente. O compromisso de Zola não é estranho ao seu fracasso em instituir a literatura como um trabalho social especializado. Ante os novos especialistas da sociedade, Zola se coloca como um Profeta. A autoridade em nome da qual Zola se pronuncia é a consciência moral de sua responsabilidade como autor. Escrever compromete, o que implica uma ética da liberdade e da justiça. Essa concepção, encarnada no mais alto nível por Zola, será teorizada por Sartre no final da Segunda Guerra Mundial.

Naquela época, o conceito de responsabilidade recuperou um significado jurídico muito concreto com o processo da purificação, no qual os escritos eram julgados como atos de traição nacional, o que implicou a condenação à morte e a execução de muitos intelectuais. Esses processos suscitaram um debate sobre a responsabilidade do escritor, que dividiu o mundo das letras em dois campos: os defensores da indulgência, em nome do "direito ao erro" e das escalas de responsabilidade, e os "intransigentes", para os quais o intelectual possui uma responsabilidade superior à das outras profissões (Sapiro, 1999, cap. 8; 2003).

Situando-se, como a maioria de seus congêneres, neste segundo campo, Sartre redefine a ideia de 
responsabilidade do escritor, conferindo-lhe cartas filosóficas de nobreza e um alcance universal que transcende a concepção nacional da responsabilidade penal. Baseando, no geral, em L'être et le néant [O ser e o nada], o conceito de responsabilidade sobre sua filosofia da liberdade, Sartre tinha levado ao extremo a definição subjetiva da responsabilidade que subentende a doutrina jurídica. ${ }^{7} \mathrm{O}$ escritor aparece assim como o melhor representante dessa liberdade existencial. Contrariamente ao artesão, cujo trabalho é o produto das normas tradicionais impessoais (o "nós" de Heidegger), o escritor cria "suas próprias regras de produção, as medidas e os critérios". Como ele explica, seu impulso criativo projeta sua subjetividade em sua obra (Sartre, 1993, p. 47). Desta forma, enquanto o conceito de responsabilidade do escritor era, até então, utilizado tanto pela justiça quanto pelos intelectuais conservadores para limitar a sua liberdade, Sartre opera uma inversão ao emanar a responsabilidade da liberdade criativa (Sapiro, 2007).

Em sua palestra proferida no dia $1^{\circ}$ de novembro de 1946, por ocasião da primeira sessão da Conferência Geral da Unesco, sobre o tema da "responsabilidade do escritor", Sartre distingue a responsabilidade limitada do sapateiro ou do médico daquela, ilimitada, do escritor. Nomear, afirma, é dar sentido a atos, é fazê-los existir na consciência comum. O escritor é responsável, pois ele dá nomes e, consequentemente, é também responsável quando opta por calar-se, pois "Calar-se é, também, falar" (Sartre, 1998, p. 21). Portanto, como explicou em sua apresentação dos Temps modernes [Tempos modernos], a revista que lançou no outono de 1945 , ele considera "Flaubert e Goncourt responsáveis pela repressão que se seguiu à Comuna de Paris, pois não escreveram uma única linha para impedi-la (Sartre, 1975, p. 13), contrariamente a Voltaire no caso Calas, a Zola no caso Dreyfus e a Gide, denunciando a administração colonial no Congo, que se expressaram. Sartre constrói, assim, uma genealogia do escritor engajado, encarnação suprema da imagem do intelectual. Se a responsabilidade representa a realização da liberdade criativa, o escritor tem, em troca, a responsabilidade de garantir a liberdade: "assim, como é isso que o escritor deseja, diremos, de uma vez por todas, que ele é responsável pela liberdade humana" (Sartre, 1998, p. 31).

Garantir a liberdade dos homens não é uma tarefa abstrata, mas um dever político. Trata-se de defendê-la concretamente, lutando contra todas as formas de opressão do homem, assim como pela sua libertação. $\mathrm{O}$ escritor não pode cumprir com esse dever político se afiliando a um partido, pois a liberdade do escritor difere da do político. O político só pode por em prática a liberdade pela violência. É claro que também existe uma possível violência das palavras, ilustrada pela propaganda ou pela publicidade, mas a literatura se destaca justamente por ser um "apelo desprovido de violência contra a liberdade" (Idem, p. 29). É pelo trabalho de desvendar o mundo, de objetivação, que o escritor deve colocar cada um diante de suas responsabilidades.

Esta teoria da literatura engajada permite a Sartre reafirmar a autonomia do escritor perante o modelo de submissão à disciplina militante representada à época pelos escritores comunistas, e de reivindicar o direito à política, contra a monopolização por especialistas.

\section{Conclusão}

Se o regime de liberdade de imprensa atribui ao autor do escrito um elevado grau de responsabilidade, a liberalização do impresso reduziu drasticamente os perigos da profissão de escritor. Ora, suas palavras correm o risco de serem desvalorizadas. Os argumentos levantados para atenuar a responsabilidade do escritor, especificamente no plano objetivo, a natureza inofensiva dos escritos, a ausência de efeitos sociais da literatura na esfera subjetiva, o distanciamento entre a intencionalidade do autor $\mathrm{e}$ a intencionalidade da obra no sentido semântico, sua irracionalidade, seus valores específicos e desinteressados tais como concebidos pela doutrina da arte pela arte revelam a tensão entre a reivindicação de autonomia da literatura e sua pretensão de universalidade. Essas alegações encobriam um risco de fazer com que o escritor parecesse apartado do mundo real, recluso em uma torre de marfim e, portanto, de fazer com que perdesse em universalidade aquilo que havia ganho em autonomia. 
Intervindo mais de um século após o regime de liberdade de imprensa, as condenações à morte de escritores e de jornalistas durante a Liberação significaram, ao final de uma guerra ideológica, a reafirmação da crença no poder das palavras, que fundou o capital simbólico dos intelectuais. A concepção subjetiva da responsabilidade, que fundamenta a teoria de Sartre da "literatura engajada”, registra este reconhecimento paradoxal reafirmando de forma espetacular o poder simbólico do escritor.

\section{Evolução a partir de 1945}

Esses processos representam marcos na conquista da liberdade de expressão. As principais evoluções desde 1945 são as seguintes:

- Reconhecimento da autonomia literária.

- Menor importância concedida ao poder da palavra em face do desenvolvimento da imagem.

- Desenvolvimento da censura administrativa, que reforça a definição objetiva da responsabilidade e evita qualquer tipo de debate.

- Essa censura é feita principalmente em nome da infância e não mais em nome do interesse nacional: há uma desnacionalização dessa responsabilidade.

Nota-se, no entanto, uma privatização das queixas devido ao crescente papel das ligas de moralidade (mesmo que o Estado ainda possa processar) - o que, neste caso, aproxima a justiça francesa da justiça norte-americana - e a multiplicação dos processos por difamação: Sévère de Régis Jauffret, que trata do caso do banqueiro Stern assassinado por sua amante, um fait divers amplamente noticiado na imprensa, mas mesmo assim Jauffret é processado pela viúva do banqueiro.

Por outro lado, confundir o autor e seus personagens é ainda frequente. A condenação de Mathieu Lindon pela Corte Europeia por seu livro Le procès de Jean-Marie Le Pen [O processo de Jean-Marie Le Pen] ilustra bem a confusão entre o autor e seus personagens (os antirracistas do romance acusam Le Pen de ser responsável de um assassinato cometido por um militante do $\left.\mathrm{FN}^{*}\right){ }^{8}$

\section{Notas}

1 Este artigo propõe o resgate histórico do surgimento da subjetividade com relação aos processos sociais de controle, por meio do papel da confissão - concebida como uma forma de reconhecimento institucionalizado da culpa - na "captura do eu".

2 Na realidade, há uma oscilação entre as duas concepções: é o que ocorre, particularmente, no final do século XIX, com a criminologia de Lombroso. Ele prioriza a hereditariedade - e, portanto, a incapacidade -, destacando a responsabilidade objetiva: a pena deve ser proporcional à periculosidade do criminoso para a sociedade e não à consciência que ele tem de seu erro (essa teoria encontrou aplicação no direito francês, com a lei de 1884 sobre os reincidentes, considerados incuráveis).

3 Aloïs Hahn se refere a uma "duplicação do controle social: aquele que passa mais pela consciência moral dos religiosos fervorosos e dos membros da comunidade que gozam de grande consideração; e o outro que se apoia mais fortemente em um monitoramento externo" (1986, p. 61). De fato, essa internalização da responsabilidade não correspondia a um controle mínimo das consciências, mas, ao contrário, implicava, entre os calvinistas, em um maior controle de todas as áreas da vida dos laicos pela introdução de uma moral ascética e de uma exigência de autocontrole, como demostrado por Max Weber (2001).

4 Ver os esclarecimentos de Chartier (1990).

5 Céline, "Réponse à l'exposé du parquet de la cour de justice”, em Gibault (1985, p. 372).

6 Os escritos de Kant e de Fichte foram reunidos no livro Qu'est-ce qu'un livre? (Kant, 1995).

7 Mesmo que, como visto anteriormente, sua definição de responsabilidade tenha se construído inicialmente com base em uma abordagem objetiva. Ver Sapiro (2006a).

8 Frente Nacional, partido político fundado por Le Pen [N. do Trad.].

\section{BIBLIOGRAFIA}

BÉNICHOU, Paul. (1973), Le sacre de l'écrivain 1750-1830: essai sur l'avènement d'un pouvoir spirituel lä̈que dans la France moderne. Paris, José Corti, 1973 (reedição Gallimard, 1996). 
BONNET, Jean-Claude. (1998), Naissance du Panthéon: essai sur le culte des grands hommes. Paris, Fayard.

CASSAGNE, Albert. ([1906] 1997), La théorie de l'art pour l'art en France chez les derniers romantiques et les premiers realists. Paris, Champ Vallon.

CHARTIER, Roger. (1990), Les origines culturelles de la Révolution Française. Paris, Seuil. . (1994), "Présentation", in Malesherbes, Mémoires sur la librairie, mémoire sur la liberté de la presse, Paris, Imprimerie Nationale.

COSER, Lewis. ([1965] 1970), Men of ideas: a sociologist's view. Nova York, The Free Press.

DIDEROT, Denis. (1976), "Lettre sur le commerce de la librairie", in . Euvres complètes, Paris, Hermann, t. 8.

FAUCONNET, Paul. (1920), La responsabilité: étude de sociologie. Paris, Alcan.

FOUCAULT, Michel. (1993), Surveiller et punir: naissance de la prison. Paris, Gallimard.

GIBAULT, François. (1985), Céline. 1944-1961: Cavalier de l'Apocalypse. Paris, Mercure de France.

HAHN, Aloïs. (1986), "Contribution à la sociologie de la confession et autres formes institutionnalisées d'aveu". Actes de la Recherche en Sciences Sociales, 62-63: 64-79.

KANT, Emmanuel. (1995), Qu'est-ce qu'un livre?. Paris, PUF.

PROCÈS FAIT AUX CHANSONS DE P.J. BÉRANGER. (1828), Paris, Baudouin Frères.

SAPIRO, Gisèle. (1999), La guerre des écrivains, 1940-1953. Paris, Fayard

(2003), "L'épuration du monde des lettres", in Marc Olivier Baruch (dir.), Une poignée de misérables: l'épuration de la société française après la Seconde Guerre Mondiale, Paris, Fayard, pp. 243-285.

. (2006A), "Responsibility and freedom: foundations of Sartre's concept of intellectual engagement". Journal of Romance Studies, 6/1-2: 31-48.

(2006B), "Vom Schrifsteller zum Intellektuellen: Die Konstruktion eines kritischen Habitus unter der Restauration”, in Ingrid Gilcher-Holtey (dir.), Zwischen den
Fronten. Positionkämpfe europä̈scher Intellektueller im 20. Jahrhundert, Akademie, pp. 25-62.

. (2007), "The writer's responsibility in France: from Flaubert to Sartre". French Politics, Culture and Society, 25/1: 1-29.

SARTRE, Jean-Paul. (1975), "Présentation des temps modernes" [1945], in ___. Qu'est-ce que la littérature?, Paris, Gallimard. [cf. qual é a data e editora de Qu'est-ce que la littérature ?1975 ou 1993]

([1948] 1993), Qu'est-ce que la littérature. Paris, Folio.

(1998), La responsabilité de l'écrivain. Paris, Verdier.

SCHNEEWIND, Jerome B. (2001), Linvention de l'autonomie: une histoire de la philosophie modern. Trad. fr. Paris, Gallimard.

TOCQUEVILLE, Alexis de. (1967), L'Ancien Régime et la Révolution. Paris, Gallimard, 1967.

WEBER, Max. (1959), Le savant et le politique. Paris, Plon. [verificar, pois segundo o tradutor no original não há esses dados] . (1974), Economie et société. Paris, Plon. [verificar, pois segundo o tradutor no original não há esses dados] . (2001), L'ethique protestante et l'esprit du capitalisme. Paris, Flammarion. 


\section{OS PROCESSOS LITERÁRIOS E A CONSTRUÇÃO DA IMAGEM DO INTELECTUAL ENGAJADO}

Gisèle Sapiro

Palavras-chave: Autonomização; Campo literário; Escritor; Responsabilidade penal; Intelectual engajado.

A autonomização do campo literário não é apenas fruto de uma reação contra o mercado, como analisou Pierre Bourdieu. Ela se opera também contra as expectativas morais e políticas que pesam sobre a literatura. Essas expectativas são codificadas na lei por meio da responsabilidade penal do autor que, de acordo com Michel Foucault, é consubstancial da emergência da figura moderna do escritor. A análise dos processos literários revela, assim, o que está em jogo nas lutas em torno da definição da responsabilidade do escritor. Ao comportar uma dupla dimensão, subjetiva e objetiva, essa responsabilidade se estabelece não só em relação ao conteúdo dos escritos, mas também em relação à forma, ao suporte, ao público visado, aos pressupostos que concernem aos efeitos sociais da literatura, à responsabilidade social atribuída ao escritor. É em relação estreita e em grande medida contra a definição penal de sua responsabilidade que os escritores construíram uma ética profissional autônoma, a qual deu lugar a duas posturas opostas: a arte pela arte, encarnada por Flaubert, e o engajamento, ilustrado por Zola e depois por Sartre.

\section{THE ROLE OF LITERARY PROCESSES IN THE AUTONOMIZATION OF THE LITERARY FIELD AND THE CONSTRUCTION OF THE IMAGE OF THE ENGAGED INTELLECTUAL}

Gisèle Sapiro

Keywords: Autonomization; Literary field; Author; Penal responsability; Engaged inteletual

The autonomization of the literary field is not only the fruit of a reaction against the market, as analyzed by Bourdieu. It is brought about as well against the moral and political expectations influencing literature. Those expectations are codified in the laws through the penal responsibility of the author, which, according to Michel Foucault, is consubstantial to the emergence of the modern figure of the author. The analysis of the literary processes discloses also what is at stake in the struggle around the definition of the writer's responsibility. Admitting a double dimension subjective and objective, this responsibility is set up not only in relation to the contents of the writings, but also in what concerns their form, their support, their target public, their assumptions related to the social effects of the literature and the social responsibility attributed to the writer. It is in close relation with, and largely against, the penal definition of the responsibility that the writers have built an autonomous professional ethics, which gave place to two opposed postures: that of the art by the art, personified by Flaubert, and that of the engagement, illustrated by Zola and, ulteriorly, by Sartre.

\section{LE RÔLE DES PROCÈS LITTÉRAIRES DANS L'AUTONOMISATION DU CHAMP LITTÉRAIRE ET LA CONSTRUCTION DE LA FIGURE DE L'INTELLECTUEL ENGAGÉ}

\section{Gisèle Sapiro}

Mots-clés: Autonomisation; Champ littéraire; Écrivain; Responsabilité pénale; Intellectuel engagé

L'autonomisation du champ littéraire n'est pas seulement le fruit d'une réaction contre le marché, comme l'a analysé Pierre Bourdieu. Elle s'opère aussi contre les attentes morales et politiques qui pèsent sur la littérature. Ces attentes sont codifiées dans la loi à travers la responsabilité pénale de l'auteur, qui, selon Michel Foucault, est consubstantielle de l'émergence de la figure de l'écrivain moderne. L'analyse des procès littéraires révèle ainsi les enjeux de lutte autour de la définition de la responsabilité de l'écrivain. Comportant une double dimension subjective et objective, cette responsabilité s'établit non seulement par rapport au contenu des écrits mais aussi à leur forme, au support, au public visé, aux présupposés concernant les effets sociaux de la littérature, à la responsabilité sociale attribuée à l'écrivain. C'est en rapport étroit et largement contre la définition pénale de sa responsabilité que les écrivains ont construit une éthique professionnelle autonome, qui a donné lieu à deux postures opposées: l'art pour l'art, incarné par Flaubert, et l'engagement, illustré par Zola puis Sartre. 